\title{
New biogeographical records of spiders and harvestmen (Arachnida: Araneae \& Opiliones) from West Siberia, including an annotated list of species
}

\author{
Yuri M. Marusik \& Seppo Koponen
}

Marusik, Yu. M. \& Koponen, S. 2015: New biogeographical records of spiders and harvestmen (Arachnida: Araneae \& Opiliones) from West Siberia, including an annotated list of species. - Entomol. Fennica 26: 165-170.

Fifty-three species of spiders and one species of harvestmen were found in the previously unstudied Gydansky Peninsula, northwestern Siberia. Distribution for each species is given. Records of certain species are of a special interest: Xysticus viduus (the northernmost locality in its range), Crosbylonia borealis (the westernmost), Oreoneta eskovi (the northernmost and the westernmost), Clubiona norvegica (the easternmost in Asia), Pachygnatha listeri, Helophora insignis and Mitopus morio (the northernmost in Asia) and Oreoneta leviceps (the southernmost in the Palaearctic). Three species, Oreoneta eskovi, Pardosa oljunae and Thaleria orientalis, are endemics of West Siberia. About two-thirds of the species are either circum-Holarctic or trans-Palaearctic.

Yu. M. Marusik, Institute for Biological Problems of the North, Portovaya Str. 18, Magadan685000 Russia; E-mail: yurmar@mail.ru

S. Koponen, Zoological Museum, Department of Biology, University of Turku, FI-20014 Turku,Finland; E-mail: sepkopo@utu.fi

Received 6 April 2015, accepted 10 April 2015

\section{Introduction}

Northern parts of West Siberia are rather poorly studied in respect of spiders in comparison to adjacent the Polar Ural or Taimyr Peninsula, northern Yakutia and Chukotka (Marusik \& Eskov 2009: map 1). An exception is the Yamal Peninsula, of which the spider fauna has dealt with in several papers (Kulczyński 1916, Koponen et al. 1998, Tanasevitch et al. 2009). Practically no spiders or harvestmen have been reported between Taimyr and Yamal Peninsula (cf. Striganova \& Poryadina 2005). We had recently an opportunity to study spiders and harvestmen collected in Tymen' Area, north of the Polar Circle or close to it in the southern part of the Gydansky Peninsula and in more southern parts of the Yamalo-Nenets Autonomous District.

\section{Materials and methods}

All material was collected by coleopterist M. A. Khrisanova (Ufa State University), and it was given to us by T. V. Piterkina (Moscow). The specimens were caught in the three geographical localities listed below (see also Fig. 1). The material treated here will be shared between the Zoological Museum of the Moscow State University and the Manchester Museum, the University of Manchester. 


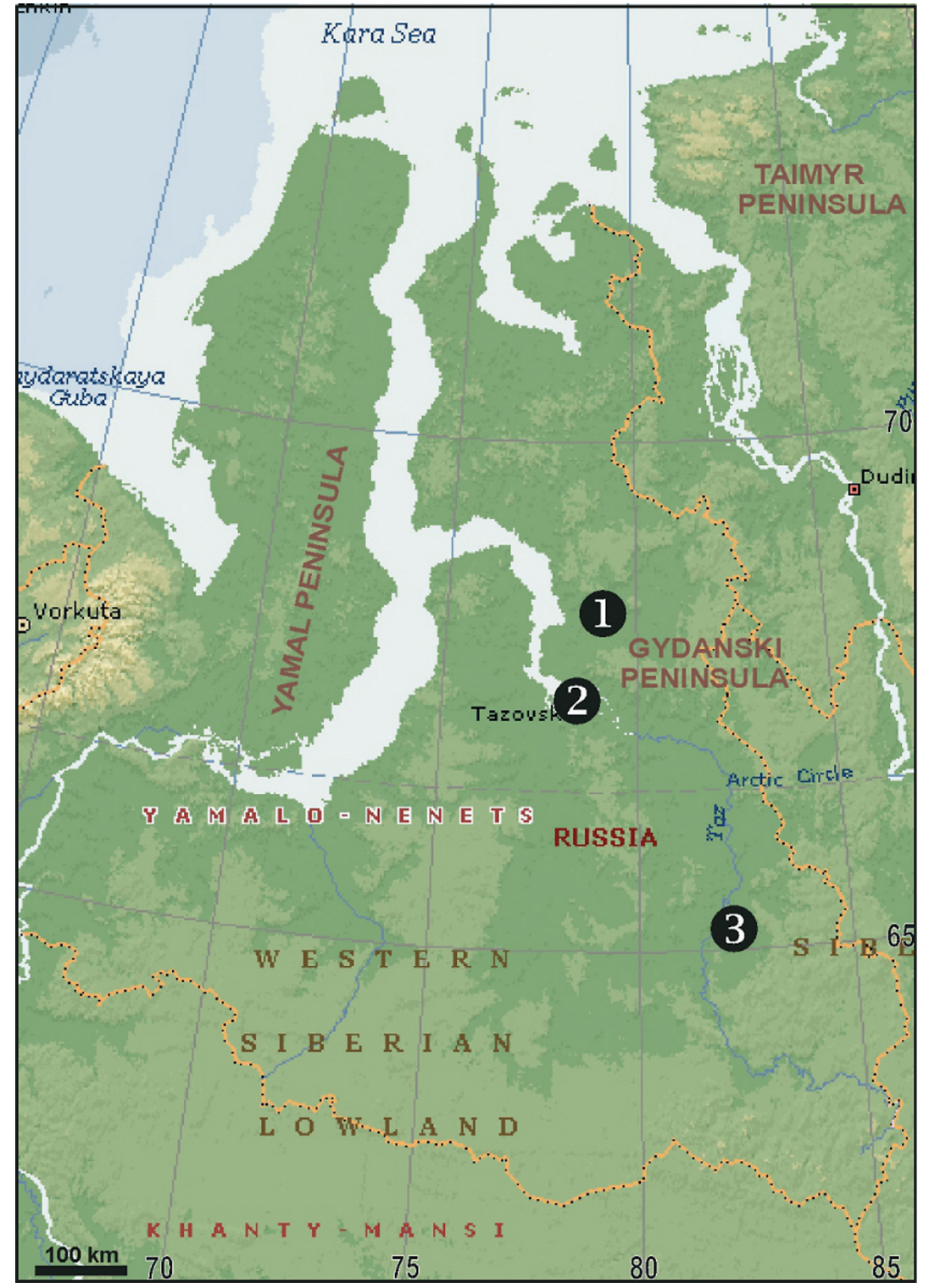

Fig. 1. Collection localities: 1) Messo Faktoria, 2) Tazovski Village and 3) Pyakol'ski Reservation.
All collecting localities belong administratively to the Tumen' Area and lie in the Yamalo-Nenets Autonomous Okrug (District), NW Siberia (Fig. 1):

1) Tazovski District, Messo-Yakhinski Zakaznik (forest reservation), Messo Faktoria, approximately $68^{\circ} 29^{\prime} 13^{\prime}$ N $79^{\circ} 22^{\prime} 33$ ' E, pitfall traps, 29.VI.-19.VII.2008

2) Tazovski Distict, Tazovski Village, approxi-

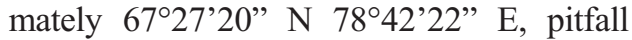
traps, 27.VI.-21.VII.2008
3) Krasnosel'kupski District, Pyakol'ski Zakaznik (protected forest reservation), approximately $65^{\circ} 22^{\prime} \mathrm{N} 82^{\circ} 17^{\prime} \mathrm{E}$, pitfall traps and sweeping, 29.VII.-11.VIII.2008.

\section{Species survey}

Below, we comment briefly upon the most interesting observations. The list of species found, the number of specimens collected, and the distribution of each species are shown in Table 1. 


\subsection{Order Araneae}

\subsubsection{Family Araneidae}

Araneus marmoreus Clerck, 1757

The species has a circum-Holarctic range. This record is the northernmost in Siberia.

Cyphepeira silvicultrix (C.L. Koch, 1835)

The species has a trans-Palaearctic range. This record is the northernmost in Siberia.

\subsubsection{Family Clubionidae}

\section{Clubiona norvegica Strand, 1900}

Although the species is considered as Holarctic (Platnick 2014), it has not been recorded from Siberia east of Yenisei River (Mikhailov 2013). In Western Siberia, it was recorded west of the Yuganski Reserve (about $74^{\circ} \mathrm{E}$ ) (Mikhailov 2003). The present record extends the known range about $4^{\circ}$ to the east.

\subsubsection{Family Dictynidae}

Arctella lapponica Holm, 1945

The species has a trans-Palaearctic-West Nearctic arcto-boreal range.

\subsubsection{Family Gnaphosidae}

\section{Gnaphosa nigerrima L. Koch, 1877}

The species has a trans-Palaearctic arcto-boreal range. In Messo-Yakhinski Reservation it was collected together with $G$. orites Chamberlin, 1922 in the same habitat. These two species have been never reported to co-occur in the same habitat.

\section{Gnaphosa sticta Kulczyński, 1908}

The species has a trans-Palaearctic range but has not been reported previously in West Siberia. Its occurrence in Gydanski Peninsula was expected.

\subsubsection{Family Linyphiidae}

Crosbylonia borealis Eskov, 1988

The species has a Siberian boreal range. Earlier, it was known east of Putorana Plateau (about $90^{\circ} \mathrm{E}$ ). Our record is the westernmost in the range and extends the known range about $12^{\circ}$ to the west.
Helophora insignis (Blackwall, 1841)

The species has a circum-Holarctic range. The record from Pyakol'ski Zakaznik is the northernmost in Asia.

Oreoneta eskovi Saaristo \& Marusik, 2004

Previously this species was known from only two localities along the Yenisei River, and one questionable locality in Altai (Saaristo \& Marusik 2004). The present record extends the known range about $10^{\circ}$ to the west.

Oreoneta leviceps (L. Koch, 1879)

The species has a Siberian-Nearctic arctic range and is known in Eurasia from the Polar Ural and across the tundra zone of Siberia. The present record is the southernmost in Asia.

\section{Porrhomma sp.}

The species could not be identified with certainty because we have only one female specimen. Two species of this genus were reported from more southern areas of Tymen' Province: $P$. pallidum Jackson, 1913 and P. pygmaeum (Blackwall, 1834) (Tanasevitch 2005).

Savignia sp.

The species can not be identified with certainty because we have only one female specimen. Savignia Blackwall, 1833 is a rather species-rich genus in Siberia.

\section{Thaleria orientalis Tanasevitch, 1984}

The species has a West Siberian boreal range and is known from the Polar Ural to the mid-Yenisei River (approximately $62^{\circ} \mathrm{N}$ ) and south to the West Sayan Mts.

Zornella cultrigera (L. Koch, 1879)

The species has almost a trans-Palaearctic range and is known from Norway to Yakutia. In northeastern Siberia it is replaced by a sibling species, Z. orientalis Marusik, Buckle et Koponen, 2007. Tanasevitch (2008) considered these two names are synonymous.

\subsubsection{Family Lycosidae}

\section{Pardosa oljunae Lobanova, 1978}

The species has a West Siberian range and is known from the South Yamal southward to Altai and Tuva (Marusik et al. 2000). 
Table 1. List of species collected at three study localities (1-3, see Fig. 1). Species range types: cH: circum-Holarctic, m: middle, N: Nearctic, S: Siberian, P: Palaearctic, t: trans, w: west. West Siberian endemics are marked with *.

1

Araneae

Araneidae

Araneus marmoreus Clerck, 1757

Araneus quadratus Clerck, 1757

Cyphepeira silvicultrix (C.L. Koch, 1835)

Larinioides cornutus (Clerck, 1757)

Larinioides patagiatus (Clerck, 1757)

Clubionidae

Clubiona norvegica Strand, 1900

Dictynidae

Arctella lapponica Holm, 1945

Gnaphosidae

Gnaphosa nigerrima L. Koch, 1877

Gnaphosa orites Chamberlin, 1922

Gnaphosa sticta Kulczyński, 1908

Haplodrassus hiemalis (Emerton, 1909)

Micaria aenea Thorell, 1871

Linyphiidae

Bathyphantes eumenis (L. Koch, 1879)

Bolephthyphantes index (Thorell, 1856)

Crosbylonia borealis Eskov, 1988

Gonatium rubens (Blackwall, 1833)

Helophora insignis (Blackwall, 1841)

Hilaira herniosa (Thorell, 1875)

Hypselistes jacksoni (O. P.-Cambridge, 1902)

Insetophantes laricetorum (Tanasevitch et Eskov, 1987)

Kaestneria pullata (O. P.-Cambridge, 1863)

Macrargus multesimus (O. P.-Cambridge, 1875)

Maso sundevalli (Westring, 1851)

Minyrioloides trifrons (O. P.-Cambridge, 1863)

*Oreoneta eskovi Saaristo et Marusik, 2004

Oreoneta leviceps (L. Koch, 1879)

Oryphantes geminus (Tanasevitch, 1982)

Porrhomma sp.

Savignia sp.

Styloctetor lehtineni Marusik et Tanasevitch, 1998

*Thaleria orientalis Tanasevitch, 1984

Zornella cultrigera (L. Koch, 1879)

Lycosidae

Alopecosa aculeata (Clerck, 1757)

Alopecosa hirtipes (Kulczyński, 1907)

Alopecosa solivaga (Kulczyński, 1901)

Pardosa atrata (Thorell, 1873)

Pardosa eiseni (Thorell, 1875)

Pardosa hyperborea (Thorell, 1872)

Pardosa indecora L. Koch, 1879

*Pardosa oljunae Lobanova, 1978

Pardosa septentrionalis (Westring, 1861)

Pardosa sp. ${ }^{1}$

Tricca alpigena (Doleschall, 1852)

Philodromidae

Thanatus arcticus Thorell, 1872

2

3

Range

1 우

1 우

7 ฟำ 1 ㅇ

$73 \overbrace{}^{\widehat{\lambda}}$ 오

60 구오

$80^{\wedge}$ 우

23

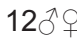

19

$1 \delta^{\lambda}$

1 우

$2 \hat{\jmath}$ 우

1 우

19

1 우

1 오

$1 \widehat{\jmath}$

13

1 우

1 우

4 우

$1 \hat{\jmath}$

34 수우

$16{ }^{\circ}$

3수우

$12 ㅅ ㅗ$

$98{ }^{ㅈ} ㅇ ㅗ$

45 구우

85 수우

39정ㅇ

1 우

73

$3 \hat{0}$

$40^{\wedge}$ 우

$50^{\wedge}$ 우

$\begin{array}{ll}10 & \mathrm{cH} \\ 10 & \mathrm{tP} \\ 10 & \mathrm{tP} \\ & \mathrm{cH} \\ 10 & \mathrm{cH}\end{array}$

WPN

tP-wN

tP

$\mathrm{cH}$

tP

SN

$\mathrm{cH}$

$\mathrm{cH}$

tP

$S$

tP

$\mathrm{cH}$

$\mathrm{cH}$

tP-wN

$S$

$\mathrm{cH}$

$\mathrm{cH}$

$\mathrm{cH}$

$\mathrm{cH}$

wS

SN

wmS

$S$

wS

tP

$\mathrm{cH}$

SN

wmS

tP

tP

WPN

wmS

wS

tP

$S$

$\mathrm{cH}$

$\mathrm{cH}$ 
Table 1, continued

\begin{tabular}{|c|c|c|c|c|}
\hline & 1 & 2 & 3 & Range \\
\hline \multicolumn{5}{|l|}{ Salticidae } \\
\hline Dendryphantes sp. & 19 & & & \\
\hline Evarcha falcata (Clerck, 1757) & & & 1 우 & wP \\
\hline \multicolumn{5}{|l|}{ Tetragnathidae } \\
\hline Pachygnatha listeri Sundevall, 1830 & & & $10^{\pi}$ & $\mathrm{tP}$ \\
\hline Tetragnatha extensa (Linnaeus, 1758) & 19 & & & $\mathrm{cH}$ \\
\hline \multicolumn{5}{|l|}{ Thomisidae } \\
\hline Misumena vatia (Clerck, 1757) & & & $1 \mathrm{j}$ & $\mathrm{cH}$ \\
\hline Ozyptila arctica Kulczyński, 1908 & $3 \delta^{\wedge}+$ & $20^{\lambda}$ & & $\mathrm{tPwN}$ \\
\hline Xysticus albidus Grese, 1909 & $1 \delta^{+}$ & $30^{\lambda}$ & & $\mathrm{tP}$ \\
\hline Xysticus britcheri Gertsch, 1934 & & $100^{\Uparrow}$ 우 & & SN \\
\hline Xysticus viduus Kulczyński, 1898 & $5 \delta^{\lambda}+x_{1}$ & & & wP \\
\hline \multicolumn{5}{|l|}{ Opiliones, Phalangiidae } \\
\hline Mitopus morio (Fabricius, 1779) & $1 \mathrm{j}$ & & & $\mathrm{cH}$ \\
\hline
\end{tabular}

1) Undescribed species.

Pardosa sp.

This is an undescribed species related to $P$. lapponica Thorell, 1872. It occurs throughout Siberia.

\subsubsection{Family Salticidae}

Dendryphantes sp.

We cannot identify with certainty a single female specimen. Four species of the genus are known in the North and Polar Urals (Esyunin \& Efimik 1996) and in Middle Siberia (Eskov 1988).

\section{Evarcha falcata (Clerck, 1757)}

The species has a Euro-Baikalian range and is known from France to the Angara River (Logunov \& Marusik 2000). The record from Pyakol'ski Zakaznik is the northernmost in Siberia, and extends the previous northernmost record (Sos'va Village, 633'N 61 $53^{\circ}$ 'E, Logunov \& Marusik 2000) about $2^{\circ}$ to the North.

\subsubsection{Family Tetragnathidae}

Pachygnatha listeri Sundevall, 1830

The species has a trans-Palaearctic range. The record from Pyakol'ski Zakaznik is the northernmost in Siberia.

\subsubsection{Family Thomisidae}

Misumena vatia (Clerck, 1757)

The species has a circum-Holarctic range. The record from Pyakol'ski Zakaznik is the northernmost in Siberia.

Xysticus viduus Kulczyński, 1898

The species has a West Palaearctic range and is known east to the Yenisei River. The record from Messo-Yakhinski Zakaznik is the northernmost in the range.

\subsection{Order Opiliones}

Family Phalangiidae Mitopus morio (Fabricius, 1799)

This species has a circum-Holarctic distribution. The present record is the northernmost in Siberia.

\section{Conclusions}

Altogether 53 species of spiders belonging to 10 families and one species of harvestman have been identified in this study. All species are new to the Gydanski Peninsula. Occurrence of most of the species in the study area was expected, since they are known from the North and Polar Ural as well 
as from the northern parts of Middle Siberia. Many present records are of a special zoogeographical interest. For example, for Araneus marmoreus, Cyphepeira silvicultrix, Helophora insignis, Evarcha falcata, Pachygnatha listeri, Misumena vatia and Mitopus morio these are the northernmost records in Siberia; for Clubiona norvegica, the easternmost locality in Siberia; and for Oreoneta leviceps, the southernmost in the Palaearctic. This is northernmost record in the range of Xysticus viduus, the westernmost of Crosbylonia borealis, and the westernmost and northernmost of Oreoneta eskovi. Three species occurring in the Gydansk Peninsula are known exclusively from Western Siberia: Oreoneta eskovi, Pardosa oljunae and Thaleria orientalis; they can be considered endemics of this region. About $30 \%$ of the spider species have a circumHolarctic range, and another $30 \%$ are trans- $\mathrm{Pa}-$ laearctic (and trans-Palaearctic-West Nearctic).

As in most northern areas, Linyphiidae (20 species) is the most species-rich spider family (e.g. Koponen 2012), but it seems that the real diversity of this family should be much higher (60 species, or even more). Our estimate is based on the approximation rule that Lycosidae always comprise about $8-10 \%$ in each local fauna in the northern Palaearctic region (Marusik \& Koponen 2002). Since 11 species of Lycosidae were found, fauna of the region should encompass not less than 110 species. The share of Linyphiidae in all Arctic faunas is over 50\% (Marusik \& Koponen 2002).

Acknowledgements. We thank M. A. Khrisanova (Ufa State University, Russia) and T. V. Piterkina (Moscow) for the material, K. G. Mikhailov (Zoological Museum of the Moscow University) for providing us with literature data and R. Leech (Edmonton, Canada) for commenting the manuscript. English of the earlier draft was kindly checked by V. Fet (Marshall University, Huntington, USA). This work was supported in part by the RFFI grant \#15-0405964 .

\section{References}

Eskov, K. Yu. 1988: Spiders (Aranei) of Middle Siberia. - In: Rogacheva, E. V. (ed.), Materials on fauna of Middle Siberia and adjacent areas of Mongolia: 101155. Akademia Nauk, Moscow. 186 pp. [In Russian.] Esyunin, S. L. \& Efimik, V. E. 1996: Catalogue of the Spi- ders (Arachnida, Aranei) of the Urals. - KMK Scientific Press. Moscow. 228 pp.

Koponen, S. 2012: Spider fauna and diversity at northern latitudes in Europe. — Euroasian Entomological Journal 11(1): 53-58.

Koponen, S., Marusik, Yu. M. \& Tanasevitch, A. V. 1998: New data on the spider fauna of the Polar Urals (Aranei). - Arthropoda Selecta 6: 109-119.

Kulczyński, W. 1916: Araneae Sibiriae occidentalis arcticae. - Mémoires de l'AcadémieImpériale des Sciences de Petrograd (8) 28(11): 1-44.

Logunov, D. V. \& Marusik, Yu. M. 2000: Miscellaneous notes on Palaearctic Salticidae (Arachnida: Aranei). - Arthropoda Selecta 8: 263-292.

Marusik, Yu. M. \& Eskov, K. Y. 2009: Spiders (Arachnida: Aranei) of the tundra zone of Russia. - In: Golovatch, S. I., Makarova, O. L., Babenko, A. B. \& Penev, L. D. (eds), Species and communities in extreme environments: 131-164. Pensoft Publishers \& KMK Scientific Press, Sofia-Moscow. 530 pp.

Marusik, Yu. M. \& Koponen, S. 2002: Diversity of spiders in boreal and arctic zones. - Journal of Arachnology 30: $205-210$.

Marusik, Yu. M., Buckle, D. J. \& Koponen, S. 2007: A survey of the Holarctic Linyphiidae (Araneae), a review of the erigonine genus Zornella Jackson, 1932. Acta Zootaxonomica Sinica 32(1): 21-24.

Marusik, Yu. M., Logunov, D.V. \& Koponen, S. 2000: Spiders of Tuva, South Siberia. — Russian Academy of Sciences, Magadan. 252 pp.

Mikhailov, K. G. 2003: The spider genus Clubiona Latreille, 1804 (Aranei: Clubionidae) in the fauna of the former USSR: 2003 update. - Arthropoda Selecta 11: 283-317.

Mikhailov, K. G. 2013: The spiders (Arachnida: Aranei) of Russia and adjacent countries: a non-annotated checklist. - Arthropoda Selecta, Suppl. 3. 262 pp.

Platnick, N. I. 2014: The World Spider Catalog, Version 15. American Museum of Natural History, online at http://research.amnh.org/iz/spiders/catalog. (Site visited on 23 March, 2015.)

Saaristo, M. I. \& Marusik, Yu. M. 2004: Revision of the Holarctic spider genus Oreoneta Kulczyński, 1894 (Arachnida: Aranei: Linyphiidae). — Arthropoda Selecta 12: 207-249.

Striganova, B. R. \& Poryadina, N. M. 2005: (Soil animal population in boreal forests of West Siberian Plain). KMK Scientific Press, Moscow. 234 pp. [in Russian].

Tanasevitch, A. V. 2005: Linyphiid spiders of the West Siberian Plain (Arachnida: Aranei). — Arthropoda Selecta 14(1): $33-88$.

Tanasevitch, A. V. 2008: New records of linyphiid spiders from Russia, with taxonomic and nomenclatural notes (Aranei: Linyphiidae). - Arthropoda Selecta 16: 115-135.

Tanasevitch, A. V., Koponen, S. \& Kaarlejarvi, E. 2009: Small collection of spiders (Aranei) from the Polar Urals and Yamal Peninsula, Russia. - Arthropoda Selecta 17(3-4): 185-190. 